\title{
Diponegoro University Heading to become a Research University (Phase I - Phase IV) Between Expectation and Reality
}

\author{
Tri Handayani ${ }^{1 *}$ Daivangga Maheswari $^{2}$ \\ ${ }^{1}$ Lecturer of History Department, Faculty of Humanities, Diponegoro University, Semarang - \\ Indonesia, \\ ${ }^{2}$ Student of History Department, Faculty of Humanities, Diponegoro University, Semarang - Indonesia,
}

\begin{abstract}
Diponegoro University is one reputable university belonging to Indonesia. This state university is located in Semarang, Central Java Province. Global dynamics have also colored its journey in implementing its traditionally assigned three missions: teaching, conducting research, and providing public services. These make this university highly confident heading to become a research university. A research university is a step to take that the university has its competitiveness to compete with the others in the world. There are some Higher Education-rankings institutions which evaluate all Higher Education Institutions in the world, such as Quacquarelli Symonds (QS) World University Rankings, Times Higher Education (THE) University Rankings, 4 International Colleges and Universities (4ICU), and Academic Ranking of World Universities (ARWU). Meanwhile, the ministry which has the function to make coordination with higher education institutions in Indonesia has also conducted higher education institutional ratings, primarily for Indonesian internal needs. The criteria of a research university refer to those evaluated by the higher education institutional ratings in the international level. A research university is a new paradigm which encourages a higher education institution in Indonesia to become highly confident to globally compete with the others in the whole world.
\end{abstract}

Keywords: Research University, Diponegoro University, Research, University Rankings

* Corresponding author : tri.handayani.undip@gmail.com 


\section{Introduction}

Higher Education is an institution functioning to develop science and technology as well as to produce intellectuals and professionals with good attitudes. Those provisions are contained in the consideration part of Law of the Republic of Indonesia Number 12 Year 2012 on Higher Education. Diponegoro University is one reputable university belonging to Indonesia and located in Semarang, the Capital City of Central Java Province. The dynamics of this higher institution as a state higher education institution follows the political dynamics developed in the government. This state higher education since first established in [1], until now has changed three times in its financial management system. First, the recent higher education financial management completely depends on government through the ministry which has the duty to make coordination with higher education. Second, Diponegoro University starting 2008 has become a Public Service Agency State Higher Education institution. This state higher education is the first institution in Indonesia which implemented a such financial management system. With this system, the financial management was completely managed by Diponegoro University, Yet the assets remain belonging to the state [2]. Third, Diponegoro University has become State-Owned Legal Entity Higher Education since 2017 [3].

A research university is the vision of Diponegoro University which was first officially used in its proposal to change the financial management system of University Diponegoro which was previously managed by the government to then be managed by the internal of Diponegoro University itself [4]. Syahrizal Abbas [5], stated that the appearing research university paradigm in response to the higher education's atmosphere, especially in Indonesia after the 1998 reformation was considered starting to fade. The spirit to produce intellectuals and professionals possessing quality, competence, and good morality had also started to fade. Meanwhile, Prof. Ir. Eko Budihardjo, M.Sc. acting as the Rector of Diponegoro University within the period of 1998-2006 stated that the problems recently faced by Diponegoro University were related to globalization make the world is changing. Vision, Missions, Strategic Plan, Operational Plan which have been well arranged and applicable during the period of 1997-2006 were in fact not in accordance with the developing situation. This higher institution has been badly loss by not obtaining even one competitive research grant until 2000. Thus, the elements of Diponegoro University leaders established the new vision from an education university into a research university [6].

\section{Method}

This research is considered as a qualitative research. The data collection was conducted through observations, interviews, and finding secondary sources. The observations were conducted by observing the development of Diponegoro University, especially in its phase IV (2015-2020) because there was no study was previously conducted during this phase [7]. The interviews were given to informants who directly experienced those events [8]. Furthermore, tracing the development of research university implementation in Indonesia was conducted through online visitations to the news in the same era and period of this research. Through the news sources from the same era, we might know what, why, who, how Diponegoro University at that time, and how was the public perception toward the research university $[9,10]$. Last but not least, the data was obtained from library research. This source was used to figure out the research university when viewed scientifically. After the data was collected, the next step was criticizing the source to figure out whether the data was appropriate or not. To obtain the supporting data, the efforts made were by interpreting or analyzing the provided various sources [11]. The next stage was reconstructing the research 
result into an article entitled "Diponegoro University heading to become a research university [Phase I - Phase IV] between Expectation and Reality" [12].

\section{Results and Discussion}

\subsection{The History of Diponegoro University Design as a Research University}

To become a research university is not an easy option because it requires a big budget for the research activities. Almost all state higher education institutions in Indonesia at the beginning of 2000's were considered as the working unit state higher education institutions. It was difficult for them to become research universities since their finances were managed by the government. In fact, Gajah Mada University which has become the State-Owned Legal Entity Higher Education based on the Government Regulation of the Republic of Indonesia Number 153 Year 2000 on the Establishment of Gadjah Mada University as the State-Owned Legal Entity has also stated the same thing [13]. The elements of Diponegoro University leaders did not give up facing the challenges although some lecturers were found pessimistic[14].

A meeting with Dr. Muhammad Nur, DEA at the beginning of 2000s and Dr.dr. Susilo Wibowo, MS., Med., Sp.And. who was at that time acting as the expert staff of Vice Rector IV (Development and Partnership Affairs) was Diponegoro's University initial point to plan itself as a research university. The meeting initially made in response to the proposal of Dr. Muhammad Nur, DEA related to the proposal of technological and professional skill development sector project (TPSDP) to the leaders of Diponegoro University which eventually made Dr.dr.Susilo Wibowo, MS., Med., Sp.And. impressed. When Dr.dr.Susilo Wibowo, MS., Med., Sp.And. became the Vice Rector on Development and Partnership Affairs within the period of 2003-2007, Dr. Muhammad Nur, DEA was promoted to become the expert staff of Vice Rector on Development and Partnership Affairs. During this period, various efforts have been made to encourage Diponegoro University to change and become a new paradigm as a research university [15]

Dr. Muhammad Nur, DEA (Now Prof. Dr. Muhammad Nur, DEA) noted that 2007 was an impressing year. At that time, Prof. Dr.dr. Susilo Wibowo, MS., Med., Sp.And. has become the Rector of Diponegoro University for the period of 2007-2011. Prof. Dr. Muhammad Nur, DEA was promoted to become the Vice Rector IV (Development and Partnership Affairs), while Prof.Dr.dr.Ign. Riwanto, SP. BD was promoted to become Vice Rector I (Academic Afairs). The Vice Rector I and Vice Rector IV in 2007 got the duties for the Rector to make a proposal to change Diponegoro University for working unit higher education into Public Service Agency Higher Education. The Rector was highly confident that Diponegoro University might well develop itself into a new paradigm that the finance was then managed by Diponegoro University, yet its assets belonging to the government. In that proposal, it was explicitly mentioned that the vision of Diponegoro University was becoming an excellent research university in $2020[16,17]$. The efforts made by the elements of Diponegoro University leaders to make this university from Public Service Agency Higher Education finally achieved its goals. This state higher education has become a state higher education which implemented the financial management patterns of Public Service Agency. The declaration was then made by the Rector of Diponegoro University on 23 September 2008. There were more state higher education institutions followed the steps made by Diponegoro University to become Public Service Agency Higher Education institutions [18]. In 2016, there were 24 Higher Education Institutions have become Public Service Agency Higher Education institutions [19] 
Other steps made by Prof.Dr. Muhammad Nur, DEA as the Vice Rector IV (Development and Partnership Affairs) were to arrange a milestone. Milestone as a working frame was to encourage all academicians at Diponegoro University to move in the same direction and at the same time. Milestone has a quite significant role to encourage the performance of Diponegoro University to systematically move due to the clear direction and target within a period of time [20]. The intended Milestone might be seen in the following Figure 1.

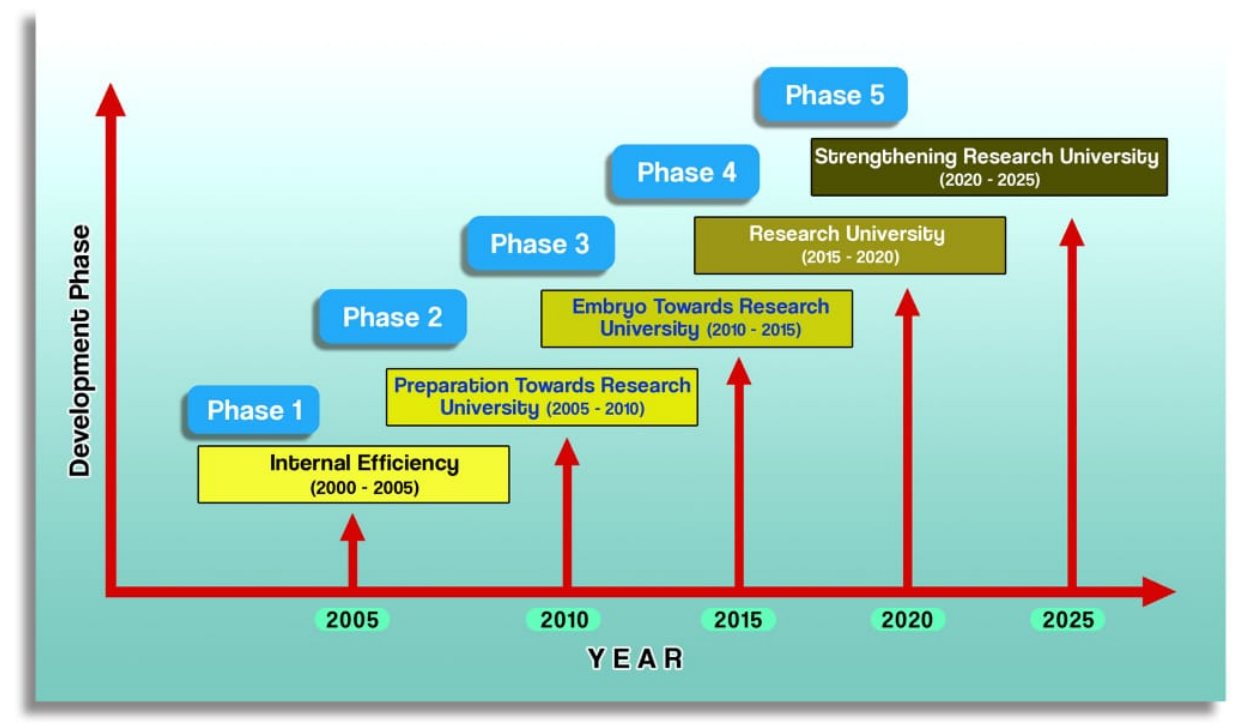

Fig. 1. Five-Year Milestone, Development Strategy of Diponegoro University in 25 Years [21]

\subsection{The Criteria of Research University}

Research is a way for a higher education institution student to understand the transformed sciences. The competences achieved by the higher education institution students will eventually make them possessing competences to be directly used by the society. The realization of those competences may be in the form of skills, government socialization programs, and others $[22,23]$. Research is one of the traditionally assigned three missions that should also be implemented by the lecturers. Those activities together with the teachinglearning, community service, and other supporting activities (such as participating in or becoming the keynote speakers in seminar activities, performing the duties as academic advisors, becoming advisors for the higher education institution students' activities, participating in training activities, and others) are measuredly made in each semester. Those working results in short period determine the appreciations earned by the lecturers for their best performances. Meanwhile, in longer period, those may become the calculated requirements for their academic promotions.

Building a research university requires a strong support from the policy and decision makers in each higher education institution. Many people have doubted that higher education institutions in Indonesia, especially the state higher education institutions are able to reach the level of a research university. A strong commitment, elements of leaders supported by all lecturers, educational staffs, higher education institution students, central and local government as well as stakeholders are a certainty to realize a research university [24][25]. 
The criteria of a research university according to Judson King as quoted by Syahrizal Abbas [26]:

“1. Lecturers and students actively involved in research.

2. Research results are used in lecturing enrichments.

3. Research implementation is well communicated either through discussion or seminar intended to obtain suggestions to develop the research implementation.

4. All or parts of research results are published in international journals.

5. Research result funding is obtained from various sources either from the related university, government, or private parties"

Prof.Dr. Muhammad Nur, DEA has the criteria of a research university formulated based on the evaluation criteria of world university rankings institutions [27]:

1. Post-Graduate Programs have reached 60 percent, while Bachelor Programs have reached 40 percent.

2. Number of Patents resulted.

3. Real Products are resulted (research products that may be directly used by the society).

4. Research results are published in international journals.

5. Research product innovation.

6. Results of research activities which are directly used by the society may become the funding supporters of higher education activities.

7. The number of doctors belonging to the high education institution has reached 60 percent of the total lecturers.

The seventh criterion is from the Directorate General of Higher Education. In addition, the professors at Diponegoro University are highly confident that all rankings may be achieved if the concept of the related higher education institution is a research university.

\subsection{University Diponegoro as a Research University}

Diponegoro University has owned a milestone as a compass to direct its all academicians to implement their activities in their higher education institution environments. The milestone was arranged based on the related higher education institution's history. The initial period of milestone was calculated starting from this higher institution did not get even a single research grant. That point was considered as the initial point of efficiency phase at the internal of Diponegoro University. When viewed based on period, it was obtained the period of 20002005. In this phase, internal efficiency was made to intensively develop the study programs. The funding on activities was competitively made. Each study program proposed a Study Program development Activity. The types of that competitive funding were: Que Project Batch III, Due Like, Technological Professionals Skills Development Project (TPSDP) Batch I, TPSDP Batch II, TPSDP Batch III, Semi Que Batch IV, Semi Que Batch V, Hibah Kompetisi A1, Hibah Kompetisi A2, Hibah Kompetisi A3. Those competitive research grants were used to develop infrastructure and management systems in each study program proposing a competitive research grant. In the same period, Diponegoro University obtained the development funds from Non-Competitive State Budget and Non-Tax State Revenue [28].

The second phase was the preparation phase as a research university (2005-2010). In this phase, lecturers who have been studying for their doctoral degrees have graduated and come back to the University. That momentum was used to build the university through their working units where they belonged to. Those new doctors have become the university agents to build each working unit where they belonged to [29]. The elements of Leaders at Diponegoro University really made various efforts to bring their higher education institution 
to national and even to international level. Those efforts included making a proposal of changing the financial management from government to financial management internally managed by Diponegoro University in 2007. This effort was successful until 2008 that Diponegoro University has changed from Working unit Higher Education Institution to Public Service Agency Higher Education Institution.

The second phase was the preparation phase as a research university (2005-2010). In this phase, the lecturers who have been studying for their doctoral degrees have graduated and come back to the University. That momentum was used to build the University through their working units. Those new doctors have become the university agents to build each working unit where they belonged to [29]. This Higher Education Institution in 2007 Has inaugurated 16 professors [30]. The elements of Leaders at University Diponegoro really made various efforts to bring their higher education institution to national and even to international level. Those efforts included making a proposal of changing the financial management from government to financial management internally managed by University Diponegoro in 2007. This effort was successful until 2008 that University Diponegoro has changed from Working unit Higher Education Institution to Public Service Agency Higher Education Institution [31, 32].

University Diponegoro as Public Service Agency Higher Education Institution might have more extensively operation to develop itself. In this phase, University Diponegoro extensively built its infrastructure using funds obtained from the Islamic Development Bank as shown in the faculty buildings in Tembalang campus, integrated laboratory, ICT Center, Training Center, Center for Business Incubator, and Diponegoro National Hospital. Those were built to make Diponegoro University get its funds to finance itself.

The third phase was a research university Embryo Phase (2010-2015). In this phase, SWOT Analysis was used to see its strengths and opportunities, as well as awareness to the existing threats and weaknesses. In this phase, the performance indicator started to be planned. This indicator was in accordance with the university objectives. In this phase, Prof. Dr. Muhammad Nur, DEA observed that activities at the environments of Diponegoro University have been in accordance with the milestone tract. Research and community service activities have significantly changed and developed shown by various funding obtained from several research schemes. The data of research activities, research distribution, and distribution of research budget values obtained by the researchers from LPPM Diponegoro University within the period of 2012-2019 showed significant development [33, 34, 35]. This development continued to the phase IV.

From all criteria of a research university, Diponegoro University has met those criteria. The authors presented two outcome profiles achieved by the researchers from Diponegoro University representing many outcome profiles which may not be all contained in this brief paper. 


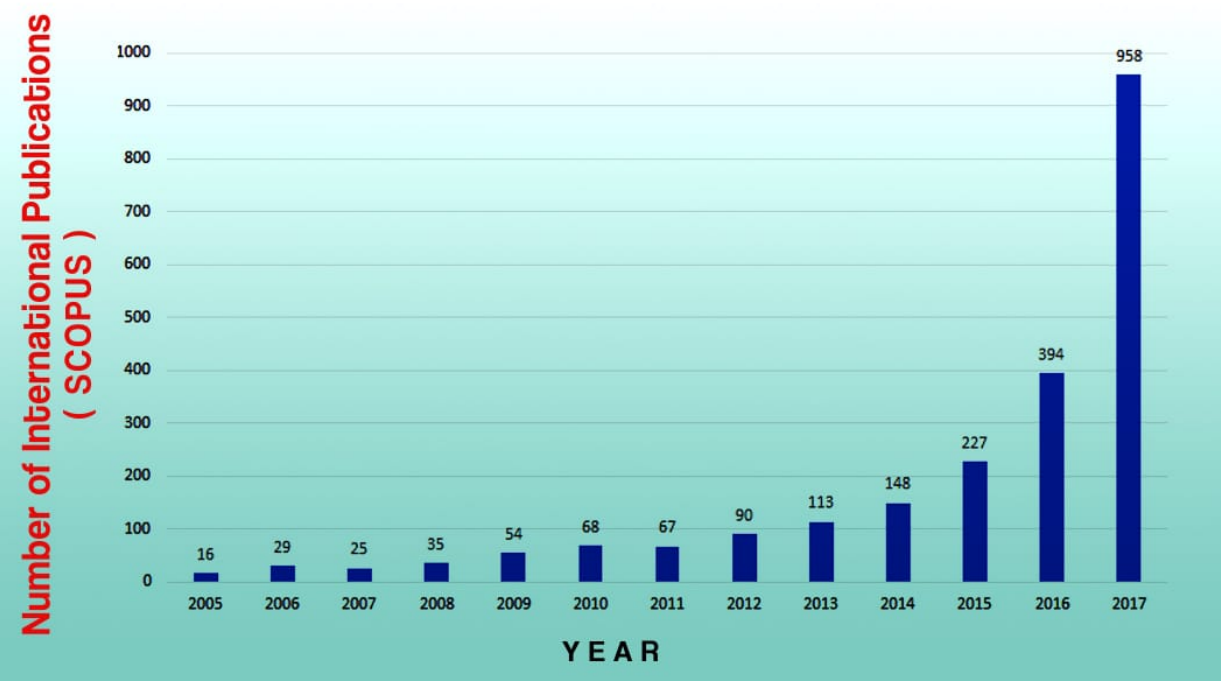

The recently updated data on January 27, 2018. Source: LPPM Undip

Fig. 2. Publication Profile of Undip in Reputable International Journals (indexed by Scopus), 20052017.

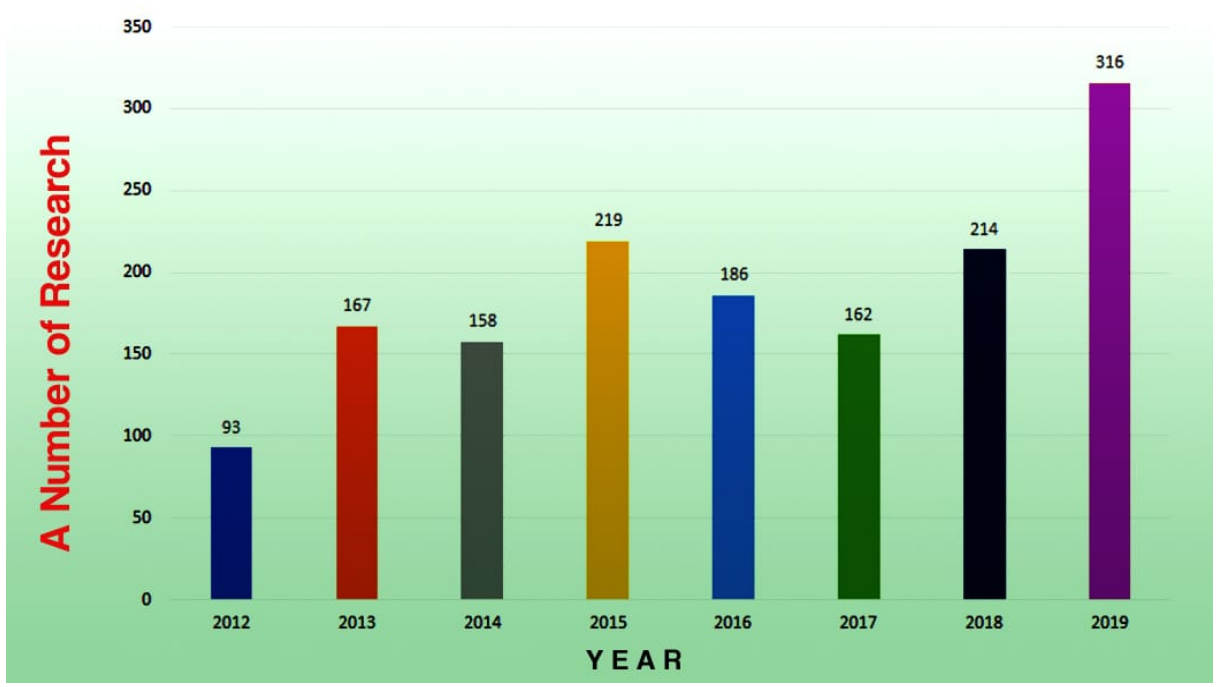

Source: LPPM Undip

Fig. 3. Profile of Total Research Titles obtaining the National Competitive Research Grants within the period of 2012-2019.

Significant development happened due to the commitment of the elements of leaders and lecturers as the implementers. It was known in 2017, when University Diponegoro has become the State-Owned Legal Entity Higher Education Institution, the Rector granted the bugdget as much as IDR 40 Billion for research activities. That value seemed to be high since 
the research outcomes were in the form of patents. Besides, the prioritized research outcomes were those which might be used as the industrial products [36]

\section{Conclusion}

Based on the explanations presented in each chapter in this paper, it is known that Diponegoro University expected to realize itself as a research university in 2020 has been achieved. Those seventh criteria have shown the indicators. The success in its achievements was due to the commitment and involvement of all academicians at Diponegoro University. Without togetherness and commitment, between expectation an reality to realize Diponegoro University as a research university is uneasy to realize. The next step which is strengthening as a research university should be continued in phase V (2020-2025).

\section{Acknowledgements}

The research is funded by DIPA University Diponegoro in 2020 fiscal year

\section{References}

1. A.M. Djuliati Suroyo, dkk, University Diponegoro, 1957 - 2012 Pergulatan Menuju University Kelas Dunia (2013)

2. Kompas.com, Pertama di Indonesia, Undip Terapkan BLU, https://nasional.kompas.com/read/2008/09/23/

20480933/pertama.di.indonesia.undip.terapkan.blu. September 23, 2008. Accessed May 29, 2020

3. https://ristekdikti.go.id/kabar/undip-resmi-menjadi-ptn-bh/. Jan 3, 2017. Accessed July 19, 2019

4. Interview with Prof.Dr. Muhammad Nur, DEA date May 29, 2020

5. Syahrizal Abbas, Manajemen Perguruan Tinggi (Beberapa Catatan) (2009)

6. A.M. Djuliati Suroyo, dkk, University Diponegoro, 1957 - 2012 Pergulatan Menuju University Kelas Dunia (2013)

7. Haris Herdiansyah, Metodologi Penelitian Kualitatif untuk Ilmu-ilmu Sosial (2011)

8. Haris Herdiansyah, Metodologi Penelitian Kualitatif untuk Ilmu-ilmu Sosial (2011)

9. Cullom Davis, Kathryn Back dan Kay MacLean, Oral History From Tape to Type (1977)

10. Wasino dan Endah Sri Hartatik, Metode Penelitian Sejarah (Dari Riset Hingga Penulisan) (2018)

11. Haris Herdiansyah, Metodologi Penelitian Kualitatif untuk Ilmu-ilmu Sosial (2011)

12. Wasino dan Endah Sri Hartatik, Metode Penelitian Sejarah (Dari Riset Hingga Penulisan) (2018)

13. Gusti, Syarat University Riset Cukup Berat, https://ugm.ac.id/id/berita/3941-syaratuniversity-riset-cukup-berat. Jan 2, 2012, Accessed May 28, 2020

14. Interview with Prof.Dr. Muhammad Nur, DEA date May 29, 2020

15. Interview with Prof.Dr. Muhammad Nur, DEA date May 29, 2020

16. Interview with Prof.Dr. Muhammad Nur, DEA date May 29, 2020 
17. University Diponegoro, Prospektus Undip 2010 (Meniti Jalan Menuju University Kelas Dunia) (2010)

18. Kompas.com, Pertama di Indonesia, Undip Terapkan BLU, https://nasional.kompas.com/read/2008/09/23/

20480933/pertama.di.indonesia.undip.terapkan.blu. September 23, 2008. Accessed May 29, 2020

19. http://www.blu/djpbn.kemenkeu.go.id/index.php?r=publication/blu/index

20. Interview with Prof.Dr. Muhammad Nur, DEA date May 29, 2020

21. University Diponegoro, Prospektus Undip 2010 (Meniti Jalan Menuju University Kelas Dunia) (2010)

22. Syahrizal Abbas, Manajemen Perguruan Tinggi (Beberapa Catatan) (2009)

23. Inas Widyanuratikah, Fokus Riset Jadi Kunci Perguruan Tinggi Kelas Dunia, https://republika.co.id/berita/q4i7y7366/fokus-riset-jadi-kunci-perguruan-tinggi-kelasdunia, Jan 22, 2020, Accessed April 18, 2020

24. Syahrizal Abbas, Manajemen Perguruan Tinggi (Beberapa Catatan) (2009)

25. Interview with Prof.Dr. Muhammad Nur, DEA date May 29, 2020

26. Syahrizal Abbas, Manajemen Perguruan Tinggi (Beberapa Catatan) (2009)

27. Interview with Prof.Dr. Muhammad Nur, DEA date May 29, 2020

28. University Diponegoro, Prospektus Undip 2010 (Meniti Jalan Menuju University Kelas Dunia) (2010)

29. Interview with Prof.Dr. Muhammad Nur, DEA date May 29, 2020

30. Antara News, Undip Kukuhkan 16 Profesor Selama 2007, https://www.antaranews.com/berita/56955/undip-kukuhkan-16-profesor-selama-2007. March 24, 2007, Accessed May 29, 2020

31. University Diponegoro, Prospektus Undip 2010 (Meniti Jalan Menuju University Kelas Dunia) (2010)

32. Interview with Prof.Dr. Muhammad Nur, DEA date May 29, 2020

33. University Diponegoro, Prospektus Undip 2010 (Meniti Jalan Menuju University Kelas Dunia) (2010)

34. A.M. Djuliati Suroyo, dkk, University Diponegoro, 1957 - 2012 Pergulatan Menuju University Kelas Dunia (2013)

35. Dokumen Sebaran Penelitian Yang Dikelola oleh LPPM Undip Tahun 2012-2019

36. Sukabumiupdate.com, Kejar Visi University Riset, Undip Semarang Kucurkan Rp40 M, https://sukabumiupdate.com/detail/edukasi/news-edukasi/21969-kejar-visiuniversity-riset-undip-semarang-kucurkan-rp-40-m 